\title{
A poesia e o sagrado em Sophia de Mello Breyner Andresen e Cecília Meireles
}

\author{
The poetry and the sacred in Sophia de Mello Breyner Andresen and Cecília Meireles \\ La poesía y lo sagrado en Sophia de Mello Breyner Andresen y Cecília Meireles
}

Márcia Helena S. Barbosa ${ }^{\circ}$

Universidade de Passo Fundo, Passo Fundo, Rio Grande do Sul, Brasil.

$\diamond$

\section{RESUMO}

Este trabalho analisa as relações entre poesia e sagrado nas obras poéticas de Sophia de M. B. Andresen e de Cecília Meireles, comparando as abordagens de que essa questão é objeto nos versos de ambas as autoras. Para estudar essas relações, recorre-se à crítica temática de base francesa, em especial às teses de Michel Collot que apontam para o fato de que poesia e sagrado apresentam uma estrutura semelhante, que os aproxima. É essa semelhança que propicia a convergência de tais elementos quando ambos são tomados como referente poético na obra da escritora brasileira e, também, na obra da autora portuguesa que foi sua leitora confessa.

Palavras-chave: Estudos de paisagem. Literaturas de língua portuguesa. Poesia e sagrado. Referente poético.

\begin{abstract}
This work analyzes the relations between poetry and sacred in the poetic works of Sophia de M. B. Andresen and Cecília Meireles, comparing the approaches to these issues in the verses of both authors. To study these relations, the French-based thematic critique is used, especially Michel Collot's theses that point to the fact that poetry and sacred have a similar structure, which brings them closer together. It is this similarity that favors the convergence of such elements when both are taken as poetic reference in the work of the Brazilian writer and also in the work of the Portuguese author who was her confessed reader.
\end{abstract}

Keywords: Landscape studies. Literatures in Portuguese. Poetry and sacred. Poetic referent.

\section{RESUMEN}

Este trabajo analiza las relaciones entre poesía y sagrado en las obras poéticas de Sophia de Mello Breyner Andresen y de Cecília Meireles, al comparar los abordajes de que ese tema es objeto en los versos de las dos autoras. Para estudiar esas relaciones se recurre a la crítica temática de base francesa, en especial a las tesis de Michel Collot que apuntan para el hecho de que poesía y sagrado presentan una estructura semejante, que los acerca. Es esa similitud que favorece la convergencia de tales elementos cuando ambos son tomados como referente poético en la obra de la escritora brasileña y también en la obra de la autora portuguesa, que fue su lectora confiesa.

Palabras clave: Estudios de paisaje. Literaturas en lengua portuguesa. Poesía y sagrado. Referente poético. 


\section{O início do percurso}

Em 1956, Sophia de M. B. Andresen (1919-2004) publica um artigo ${ }^{1} \mathrm{em}$ que aponta aqueles que seriam os principais traços da poesia de Cecília Meireles (19011964). $\mathrm{Na}$ opinião da autora portuguesa, a obra poética da escritora brasileira é "construída sobre dualidades". Trata-se de "uma poesia ao mesmo tempo clássica e romântica, objectiva e subjectiva, serena e desesperada, intemporal, desligada, distante e humanamente cheia de paixões e lágrimas", que, estando "suspensa entre reinos divididos", precisa "procurar constantemente a sua unidade, resolver a sua divisão, reunir os seus membros dispersos" (ANDRESEN, 2000, p.62). Lembrar tais afirmações, no momento em que se propõe uma leitura comparativa entre os versos de ambas as autoras, pode ser o início de um percurso capaz de mostrar que a dualidade ou divisão percebida na poesia de Cecília Meireles por essa leitora especial que é Sophia de M. B. Andresen constitui-se, em verdade, em uma característica comum às obras das duas poetisas em questão. O desejo de ver o que não se dá a ver - aquilo que, mesmo pressentido, é invisível - e a vontade de dizer o que, embora indizível, continua a prometer-se nas imagens e a sussurrar aos ouvidos mais atentos, marcam, de forma indelével, as obras de Sophia de M. B. Andresen e de Cecília Meireles, promovendo, no decorrer da produção dessas escritoras, uma aproximação entre a poesia e o sagrado. Esses dois elementos possuem uma estrutura semelhante e pressupõem, justamente, o desejo nunca plenamente realizado que se acaba de mencionar, e que é alimentado por uma ausência sempre presente. Para analisar a convergência dessas duas temáticas nos textos da autora brasileira e daquela que é sua leitora confessa, recorre-se às teses sobre o referente poético formuladas pelo poeta e pesquisador francês Michel Collot, tomando como corpora, no caso de Sophia de M. B. Andresen, poemas contidos nos três tomos que integram a Obra poética da escritora, produzida entre 1944 e 1989. Do mesmo modo, o exame relativo à poesia de Cecília Meireles focaliza textos que foram reunidos na Poesia completa da autora, pertencentes a livros escritos e publicados em diferentes épocas, dos anos 20 até sua morte, em $1964 .^{2}$

\footnotetext{
Esse artigo, originalmente publicado na revista Cidade Nova, IV série, n. 6, p.341-352, nov., foi reproduzido em um fascículo da revista Metamorfoses publicado em 2000 e organizado por Eucanaã Ferraz, edição essa que é utilizada como referência para as citações do texto de autoria de Sophia de M. B. Andresen feitas neste trabalho.

2 Para identificar, ao longo da análise, os livros de Sophia de M. B. Andresen em que estão inseridos os poemas citados e/ou comentados, serão utilizadas as seguintes convenções: Poesia (PS), Dia do mar (DM), Coral (CR), Mar novo (MN), Livro sexto (LS), Geografia (GF), Dual (DL), O nome das coisas (NC), Navegações (NV), Ilhas (IL). Do mesmo modo, no caso dos livros de Cecília Meirelles, serão adotadas as convenções a saber: Viagem (VG), Vaga música (VM), Mar absoluto e outros poemas (MA), Retrato natural (RN), O aeronauta (AN), Metal rosicler (MR), Solombra (SB), Poema dos poemas (PP), Poemas III (PM).
}

\section{Duas vozes ao encontro do indizível}

Em seus estudos teórico-críticos, Collot (1989) adota uma perspectiva fenomenológica, a fim de examinar o problema da referência no texto poético, e afirma que o mundo ao encontro do qual a poesia nos leva é o desdobramento de uma realidade que se propõe, a cada vez, de maneira diferente à consciência dos sujeitos, e não um objeto exterior sempre igual a si mesmo - ou uma coisa particular que seria possível identificar -, não podendo, assim, ser encarado sob o modo da objetividade e da identidade. O mundo não é, mas se "mundifica", como explica o teórico, ao tomar emprestada uma expressão de Heidegger, e a invenção poética responde a essa metamorfose constante da realidade. O poeta é fiel a tal movimento pelo qual o mundo, a todo instante, pode se revelar Outro. Essa modificação permanente, que causa espanto aos olhos, ocorre porque o mundo jamais é dado senão como horizonte de uma visada distinta, por princípio, de qualquer outro ponto de vista possível. O referente do poema é, portanto, um "universo imaginário", que constitui uma versão singular, uma visão subjetiva do mundo. $\mathrm{O}$ fato de que o mundo não é visto senão por um sujeito mostra que a objetividade é que é uma ficção, enquanto o imaginário é, ao contrário, um instrumento de conhecimento do real.

Desse modo, a poesia promove a redefinição do referente, que, nas palavras de Lefebvre citadas por Collot, "pode ser concebido 'como uma espécie de reservatório contendo a totalidade das experiências que temos do objeto"'. (COLLOT, 1989, p. 176, tradução nossa). ${ }^{3}$ Dito de outra forma, o referente poético, que inclui em si os aspectos invisíveis do objeto, "é a coisa com todos os seus horizontes possíveis, todas as perspectivas que nós podemos ter sobre ela, e, a partir dela, sobre o mundo"4 (COLLOT, 1989, p. 176, tradução nossa). A revelação da coisa pressupõe, assim, um encobrimento, pois o horizonte que está implicado em seu aparecer contém, em reserva, a possibilidade de outras aparições.

Com base nessas afirmações, pode-se entender a intransitividade da escrita poética como transitividade absoluta: porque não visa a um objeto específico, ela se abre sobre a abertura sem fundo do Ser, sobre um vazio que contém qualquer coisa, e procura dizer, através de suas figuras, um infigurável. A referência poética é, então, vazia de conteúdo. O referente do qual o poema está em busca é inacessível, o horizonte ao qual ele tende está destinado a faltar, e, nesse insucesso, o teórico propõe

\footnotetext{
3 Do original: La poésie nous invite donc à redefinir le référent, que l'on peut concevoir comme une sorte de réservoir contenant la totalité des expériences que nous avons de l'objet'.

4 Do original: Le référent poétique c'est la chose avec tous ses horizons possibles, toutes les perspectives que nous pouvons avoir sur ele, et, à partir d'elle, sur le monde.
} 
que se leia uma abordagem da verdade do Ser, que está presente por sua ausência. Se não visasse ao impossível, a uma presença ausente, o poema, assim privado de sua transcendência, não poderia se tornar presente enquanto tal, e seria rebaixado à categoria de um puro e simples objeto. Dessa forma, tal como o horizonte, o referente do poema é, ao mesmo tempo, inatingível e indispensável; "ele é o ponto de fuga em função do qual se organizam e convergem as linhas da paisagem textual" 5 (COLLOT, 1989, p. 182, tradução nossa). Mediante o apagamento da situação que lhe deu origem, o poema sugere que há em todo evento um fundo insondável que impede de reduzilo a uma realidade circunscrita e identificável, ao torná-lo um advento sempre enigmático do mundo. Portanto, o horizonte é, simultaneamente, a fonte infinita da poesia no que lhe propõe sempre de despercebido a revelar - e o encobrimento que lhe interdita o acesso à totalidade do visível. Sendo inesgotável, a coisa está sempre para além do que dela se diz, de modo que o poeta é onipotente para dar à luz relações surpreendentes entre as coisas, por meio de palavras imprevistas, mas impotente para atingir o próprio ser da coisa. Essa incapacidade do poema de coincidir com a coisa faz da referência poética a experiência dolorosa da separação entre palavra e coisa. E uma tensão permanente instaura-se, porque a referência poética não pode abolir completamente tal distância, nem se resignar a ela. A poesia tem no mundo a sua pátria, porém precisa exilar-se dele caso queira dizê-lo. Daí advém a decepção, que é a tonalidade afetiva do poema moderno e que dá a medida da decepção ontológica da poesia. É a dedicação do poeta a uma tarefa decepcionante, porque infinita, que torna o mundo ilimitado.

Entretanto, talvez seja justamente nesse insucesso em encontrar seu objeto que consista a verdade do poema, pois, conforme explica Collot (1989, p.184, tradução nossa), a coisa é reconhecida como tal pelo sentimento que provoca de que não pode ser nomeada; ela afirma sua irredutível alteridade na resistência que opõe a qualquer denominação. É por essa razão que o teórico afirma: "Chamar uma coisa por seu nome não é convocá-la a comparecer diante de nós, é fazê-la aparecer em sua própria distância, torná-la presente no coração de sua ausência"“ (COLLOT, 1989, p. 186, tradução nossa). Dessa maneira, é condição para fazer-se poeta tomar consciência de que a relação transparente e imediata entre palavras e coisas se constitui em uma ilusão, própria à linguagem "referencial". O poeta precisa reconhecer que está sujeito ao inexprimível, que a linguagem não tem o

\footnotetext{
5 Do original: il est le point de fuite en fonction duquel s'organisent et convergent les lignes du paysage textuel.

6 Do original: Apeller une chose par son nom, ce n'est pas la convoquer à comparaitre devant nous, c'est la faire apparaître dans son éloignement même, la rendre presente au coeur de son absence [...].
}

poder de dizer tudo, que toda referência é incompleta e inadequada. Assim, tendo um referente que não se deixa dizer, o poema, ao final de seu percurso, reencontra sua origem silenciosa: seu horizonte último é o silêncio. São os brancos que materializam sobre a página esse horizonte de invisibilidade e de indizibilidade; é por seu intermédio que "o poema se comunica com o silêncio interior ao mundo", que ele "diz mais do que as palavras poderiam dizer"7 (COLLOT, 1989, p. 184, tradução nossa). É exatamente em virtude dessa relação constitutiva com um horizonte de invisibilidade e de indizibilidade que a poesia tem a possibilidade de encontrar a experiência mística, disposta a acolher em si o sagrado. A experiência da distância entre aquilo que é dito e o indizível, entre o significado e o não significável, é comum a ambas. $\mathrm{O}$ sagrado e a poesia "põem em jogo a estrutura de horizonte, a presença e a ausência, o visível e o invisível, o próximo e o distante" (COLLOT, 1989, p. 185, tradução nossa). Se o sagrado caracteriza-se por sua retração, e só se mostra escondendo-se, a poesia consiste em um espaço reservado ao que se reserva, em uma abertura que dá à luz a obscuridade do Ser. Devido a essa afinidade de estrutura que as une, a palavra sagrada e a palavra poética estiveram frequentemente ligadas no curso da história.

Ressalta-se que os conceitos até aqui retomados constam em La poésie moderne et la structure d'horizon, livro publicado por Collot em 1989, no qual a ênfase recai sobre a incapacidade da poesia de coincidir com as coisas. Contudo, em Le corps cosmos, lançado em 2008, o teórico põe em evidência a possibilidade que a linguagem tem de se comunicar com as coisas e recorre a ideias de Francis Ponge para afirmar: "Todo o trabalho do poeta consistirá em restituir à língua 'essa densidade, essa materialidade, essa espessura [...] que a torna tão concreta quanto o mundo físico""9 (COLLOT, 2008, p. 65). Trata-se de conceder atenção à materialidade fônica e gráfica das palavras ${ }^{10}$, conferindo-lhes uma consistência análoga à "substância" das coisas, pois é por meio de sua espessura que se comunicam com as coisas, complementa o teórico (COLLOT, 2008, p. 65, tradução nossa). Em Poética e filosofia da paisagem, Collot (2013) mostra que muitos poetas contemporâneos tentam reparar esse afastamento entre homem e paisagem, a fim de reencontrar uma relação perdida com o mundo sensível. A poesia não pode

\footnotetext{
Do original: Par ses blancs, le poème comunique avec le silence intérieur au monde, il dit plus que les mots ne sauraient dire [...].

8 Do. original: L'un et l'autre mettent en jeu la structure d'horizon, la presence et l'absence, le visible et l'invisible, le proche et le lointoin [...].

9 Do original: Tout le travail du poéte consistera à restituer à la langue 'cette denssité, cette matérialité, cette épaisseur [...] qui la rende aussi concrète que le monde physique'.

10 A análise dessa materialidade das palavras é examinada por Collot em $L a$ matière émotion (1997).
} 
eximir-se dessa separação, mas tende a experimentar consertá-la ou compensá-la.

Nas obras poéticas examinadas a seguir, pode ser percebida a afinidade de estrutura entre poesia e sagrado. Entretanto, para além de dar à luz a obscuridade do Ser, os versos de ambas as escritoras reconhecem que a linguagem poética procura comunicar-se com as coisas.

O poema "Pudesse eu" (PS), que faz parte de Poesia, mostra que o mundo visado pela poesia de Sophia de M. B. Andresen possui múltiplas faces, apresentando-se, a cada momento, de maneira diferente: "Pudesse eu não ter laços nem limites/Ó vida de mil faces transbordantes/ Pra poder responder aos teus convites [...]" (ANDRESEN, 1990, p.35). A metamorfose constante da realidade provoca surpresa e convoca o eu lírico a acompanhar esse movimento pelo qual o mundo, a todo instante, revelase outro a seus olhos. Essa convocação toma a forma de convites aos quais a poesia não é capaz de responder de modo pleno, pois possui limites que a impedem de abarcar a permanente "mundificação" da realidade. Nessa mesma direção, a poesia de Cecília Meireles manifesta o desejo do eu lírico de acompanhar a incessante metamorfose do mundo e, ao mesmo tempo, aponta os obstáculos que se interpõem à realização dessa vontade. No poema intitulado "Noite" (MA), a noite dirige um convite ao sujeito poético, mas logo "se esconde", pois, ao transbordar "por todos os cantos", escapa a qualquer tentativa feita no sentido de abarcá-la. E o sujeito conclui que não é apenas o mundo, mas também o seu próprio eu que se mostra constante somente em sua transformação. Dessa forma, ambos, mundo e sujeito, às vezes, são "nenhum” e, em seguida, "tantos!": “Tão perto!/ Tão longe!/ Por onde é o deserto?/ Às vezes,/ responde,/ de perto,/ de longe./ Mas depois/ se esconde./ Somos um/ ou dois?/ Às vezes,/ nenhum./ E em seguida,/ tantos!" (MEIRELES, 1994, p. 335-336).

Essa concepção do referente poético comum a tais escritoras aprofunda-se, em suas obras, mediante a negação da objetividade e da transparência na poesia. O texto de Sophia de M. B. Andresen intitulado "Arte Poética - II" (GF) explicita a ideia de que o poema fala não de um objeto específico, mas das experiências que a autora tem do objeto e do modo como este se apresenta sob determinadas perspectivas, ou seja, da coisa com todos os seus horizontes possíveis: “[...] o poema fala [...] de uma vida concreta: ângulo da janela, ressonância das ruas, das cidades e dos quartos, sombra dos muros, aparição dos rostos, silêncio, distância e brilho das estrelas, respiração da noite, perfume da tília e do orégão" (ANDRESEN, 1991 b, p. 95). Nessa afirmação, a escritora evidencia que o referente do poema é um universo imaginário que consiste em uma visão subjetiva da realidade, e que a poesia, ou o imaginário, é concebido por ela como um instrumento de conhecimento do real, como a sua "explicação com o universo". Aberta sobre um vazio que contém qualquer objeto, ou a possibilidade de inumeráveis aparições de um mesmo objeto, a poesia de Sophia de M. B. Andresen procura dizer esse infigurável, o que a aproxima de obras de outros artistas. É isso o que se verifica ao ler o texto em prosa poética intitulado "Landgrave ou Maria Helena Vieira da Silva" (IL), que fala do quadro chamado Landgrave, da pintora portuguesa: "Lugar de aparição. [...] Onde do visível emerge a aparição" (ANDRESEN, 1991b, p. 341). A escritora enfatiza, nessa evocação, o fato de que o mundo visado pela arte não pode ser encarado sob o modo da objetividade e da identidade, pois do visível emerge o invisível, que causa espanto aos olhos do sujeito e desvela a obscuridade do Ser, oculta sob a aparência. Os aspectos desenvolvidos pela autora nos poemas citados são sintetizados nos versos de "A escrita" (IL): "[...] a escrita exige [...] coisas que se veem como quem vê outra coisa" (ANDRESEN, 1991b, p.328).

A existência desse fundo insondável, que requer do poeta uma fidelidade ao movimento constante, à permanente metamorfose do mundo, também aproxima Sophia de M. B. Andresen de Cecília Meireles. A escritora brasileira põe sua atenção sobre a coisa com todos os seus horizontes ou aparições possíveis, conforme se lê em "Noite" (MA). Nesse poema, já comentado, o instante em que se dá o transbordamento da vida é caracterizado como um despertar do qual emerge o invisível: "A vida/ transborda/ por todos/ os cantos./ Acorda/ com modos/ de puro/ esplendor" (MEIRELES, 1994, p.335-336). Em "Destino" (VG), verifica-se, ainda, a maneira como a obra da autora brasileira aborda a perseguição em que se lança a poetisa, "pastora de nuvens", atrás de seu "vário rebanho" (MEIRELES, 1994, p. 155-156). A dificuldade do ofício assumido por tal pastora reside, em parte, na instabilidade desse gado que ela precisa capturar, reunir - mas que nunca se dá a ver com a mesma forma - e, consequentemente, na inconstância do canto que depende da apreensão de elementos assim tão fugidios e afeitos à dispersão: "Pastora de nuvens, cada luz colore/ meu canto e meu gado de tintas diversas./ Por todos os lados o vento revolve/ os velos instáveis das reses dispersas". $\mathrm{O}$ fato de o rebanho surgir sempre como aparição e não como aparência, de extraviar-se, deve-se ao efeito de deslumbramento que estrelas e luas exercem sobre ele: "Estrelas e luas que jorram deslumbram/ o gado inconstante que se me extravia". À instabilidade do rebanho que é perseguido, soma-se a falta de limites, de fixidez e de segurança da campina. A "pastora de nuvens" movimenta-se sobre um prado que também é "móvel", ou sobre uma "planície aérea" e infinita, na qual não existe a possibilidade de evitar os abismos, pois o que essa experiência exige do sujeito é a abertura para o fundo 
insondável que há em todo evento e que o converte em um advento enigmático do mundo:

Pastora de nuvens, por muito que espere,

Não há quem me explique meu vário rebanho.

Perdida atrás ele na planície aérea,

Não sei se o conduzo, não sei se o acompanho.

(Pastores da terra, que saltais abismos, nunca

entendereis a minha condição.

Pensais que há firmezas, pensais que há limites.

Eu, não.) (MEIRELES, 1994, p. 155).

O mar é um dos elementos que comparecem nas obras de Sophia de M. B. Andresen e de Cecília Meireles em suas várias e distintas aparições, convertendo-se em um objeto que é dado enquanto horizonte, isto é, como fonte infinita da poesia e, simultaneamente, como encobrimento, ao interditar o acesso à totalidade do visível. Assim, sendo inesgotável, o mar está sempre para além do que dele se diz. Por isso, configura-se como um "mar sem fundo, mar sem fim" (ANDRESEN, 1990, p. 84), no poema intitulado "Mar sonoro" (DM). "A vaga" (DM) é, talvez, o que melhor expõe as constantes metamorfoses dessa paisagem na obra da autora, caracterizando o mar como um objeto sempre diferente de si mesmo nas diversas experiências do eu lírico. O sujeito poético demonstra que o mar assemelha-se a inúmeros seres - "toiro", "cavalgada", "cavaleiro", "mulher", "bailarina" -, dependendo da perspectiva sob a qual é observado, e assim concentra em um mesmo poema uma gama de aparições desse objeto que, em geral, surgem em outros textos, uma de cada vez: "Como toiro arremete/ Mas sacode a crina/ Como cavalgada// Seu próprio cavalo/ Como cavaleiro/ Força e chicoteia/ Porém é mulher/ Deitada na areia/ Ou é bailarina/ Que sem pés passeia" (ANDRESEN, 1991, p. 104). A essas aparições, soma-se outra, igualmente recorrente na poesia da escritora - a do mar das singraduras, que não raro se transforma no mar primordial e que atesta a manifestação momentânea do sagrado. O poema VII do conjunto intitulado "Deriva" (NV) é um dos que associam o descobrimento, a aparição de novas terras, ao fenômeno da criação do mundo: "Outros dirão senhor as singraduras/ Eu vos direi a praia onde luzia/ A primitiva manhã da criação" (ANDRESEN, 1991b, p.267). Também se destaca o poema intitulado "O sol o muro o mar" (IL), no qual o mar adquire um brilho especial que o aproxima do sagrado e que se converte em apelo ao sujeito que o vê: "O mar ergue o seu radioso sorrir de estátua arcaica./ Toda a luz se azula./ Reconhecemos nossa inata alegria: a evidência do/ lugar sagrado" (ANDRESEN, 1991b, p. 318-319).

Conforme demonstra o poema "Crepúsculo dos deuses" (GF), desde que "[...] se apagaram/ Os antigos deuses sol no interior das coisas/ [...] se abriu o vazio que nos separa das coisas", razão pela qual "Somos alucinados pela ausência bebidos pela ausência" (ANDRESEN, 1991b, p. 70). Entretanto, o advento do mundo a ressoar nos objetos, isto é, o retorno do elemento divino à superfície das coisas, é visto com frequência na poesia de Sophia de M. B. Andresen, que celebra o restabelecimento da aliança com o sagrado, ainda que essa visita, em um universo apartado dos deuses, seja sempre breve e fugidia. E o mar - assim como outros lugares é capaz de readquirir, momentaneamente, sua condição de reino, tornando-se "Puro espaço e lúcida unidade" (ANDRESEN, 1991a, p.60) no poema "Liberdade" $(\mathrm{MN})$, e promovendo a reunião temporária do ser humano com o divino por meio das coisas. Nesses lugares é que as palavras são "o nome das coisas" (ANDRESEN, 1991a, p. 109), conforme se lê no poema denominado

"Ressurgiremos" (MN). Assim, diante do mar e em um momento de descoberta como o que é evocado em "Mundo nomeado ou descoberta das ilhas" (GF), configura-se o retorno ao dia inicial, que restaura a relação de correspondência entre os objetos e as palavras: "Iam de cabo em cabo nomeando/ Baías promontórios enseadas:/ Encostas e praias surgiam/ Como sendo chamadas". Desse modo, "as coisas mergulhadas no sem-nome/ [...] Uma por uma ao seu nome respondiam/ Como sendo criadas" (ANDRESEN, 1991b, p.14). A possibilidade de restabelecimento dessa aliança leva o eu lírico a colocar-se à escuta do silêncio, a fim de tentar ouvir o nome das coisas por elas próprias pronunciado. Nas duas primeiras estrofes de "Poema" (GF), o sujeito, movido pela expectativa de encontrar Deus "no mundo", declarase disponível para procurá-lo, ao escutar o apelo das coisas: "O meu viver escuta/ A frase que de coisa em coisa silabada/ Grava no espaço e no tempo a sua escrita// Não trago Deus em mim mas no mundo o procuro/ Sabendo que o real o mostrará" (ANDRESEN, 1991b, p. 89).

Nesse poema, o apelo das coisas soa como se fosse uma frase ao alcance do ouvido; em outros, contudo, os objetos resistem à palavra, negando-se a serem ditos, e essa sintonia se desfaz. Sendo transitória a reunião das coisas e, consequentemente, dos seres humanos com o divino, os versos da autora mostram que a poesia se ressente dessa quebra. Em "A raiz da paisagem" (CR), percebe-se que, devido a tal divisão, os objetos perdem o nome, calam-se e ausentam-se: "A raiz da paisagem foi cortada./ Tudo fluctua ausente e dividido,/ Tudo fluctua sem nome e sem ruído" (ANDRESEN, 1990, p.222). Em outros poemas, também se constata que a ruptura da aliança com o sagrado retira da poesia o poder de dizer as coisas, como se pode perceber em "O jardim e a noite" (PS). A primeira estrofe aborda a tentativa frustrada do sujeito poético de unir sua alma à noite - "Atravessei o jardim solitário e sem lua,/ [...] Para tentar como outrora, 
Unir a minha alma à tua,/ Ó grande noite solitária e sonhadora" -, gesto que se repete, sem resultado, na segunda estrofe, dessa vez em relação à "terra negra dos canteiros". Como "Calouse a terra", conforme se lê no segundo verso da terceira estrofe, o eu lírico lança mão de um último recurso: "Murmurei as palavras em que outrora/ Para mim sempre existia/ O gesto dum impulso./ Palavras que eu despi da sua literatura,/ Para lhes dar a sua forma primitiva e pura,/ De fórmulas de magia". Porém, a noite "Continuou distante e inatingível/ Sem me deixar penetrar no seu segredo" (ANDRESEN, 1990, p. 20-21). Revela-se aí a impotência do poeta para atingir o próprio ser da coisa, ou a incapacidade do poema de coincidir com a coisa, que, sendo inesgotável, guarda um segredo, está sempre para além do que dela se diz. Deriva dessa distância entre palavra e coisa a decepção do poeta.

Entretanto, é justamente o fato de a linguagem poética não alcançar a noite nem a terra - as quais continuam distantes e inatingíveis - que afirma a irredutível alteridade desses elementos. Assim, chamar essas coisas por seu nome, para a poesia da autora portuguesa, é fazê-las aparecer em sua própria distância e tornar a sua ausência presente. Por isso, nos versos seguintes, o poema fala do indizível, daquilo que, embora esteja "vivo", é visto apenas como "sombra escura" e ouvido somente como "silêncio": "Tomei nas minhas mãos a sombra escura/ E embalei o silêncio nos meus ombros./ Tudo em minha volta estava vivo/ Mas nada pôde acordar dos seus escombros/ O meu grande êxtase perdido" (ANDRESEN, 1990, p.21) . Dessa maneira, a consciência de que o referente poético não se deixa dizer, conduz o poema, ao final de seu percurso, a reencontrar sua origem, seu horizonte último, que é o silêncio. Em "Horizonte vazio" (DM) novamente é abordado o tema do apelo ou convite feito pelas coisas, que é seguido de uma espera malograda por parte do poeta, uma vez que dela não surge o poema. Após o "chamamento infinito dos espaços", tem lugar a intensidade da espera, que acaba comprometendo a realização da promessa: "Horizonte vazio em que nada resta/ Dessa fabulosa festa/ Que um dia te iluminou.// As tuas linhas outrora foram fundas e vastas,/ Mas hoje estão vazias e gastas/E foi o meu desejo que as gastou". Observa-se aí que o olhar do eu lírico fixase sobre o horizonte, que figura o vazio onde poderia ser fomentado o nascimento do poema. Entretanto, a aridez impede esse nascimento, e as palavras que aspirariam preencher esse espaço de indeterminação jamais são ditas: "Horizonte vazio, esqueleto do meu sonho./ Árvore morta sem fruto,/ Em teu redor deponho/ A solidão, o caos e o luto" (ANDRESEN, 1990, p. 143).

Assim, o poema imanente é um sonho que o eu lírico projeta para o futuro em "Ali, então" (GF): "Ali então em pleno mundo antigo/ [...]// A sombra da videira há-de poisar/ Em nossas mãos e havemos de habitar/ O silêncio das luas e do trigo/ No instante ameaçado e prometido// E os poemas serão o próprio ar/ - Canto do ser, inteiro e reunido [...]" (ANDRESEN, 1991b, p. 58). E o mesmo ocorre em no poema "Ressurgiremos" (LS), já comentado: "Ressurgiremos ali onde as palavras/ São o nome das coisas" (ANDRESEN, 1991a, p. 109). O fato de o eu lírico projetar esse sonho para o futuro, não o leva, todavia, a renunciar, no presente, à busca do poema imanente. No poema intitulado "Ó poesia - quanto te pedi" (CR), o sujeito alude à divisão que separou o homem das coisas e o apartou dos deuses, sugerindo que aquilo que espera da poesia é a recomposição dessa aliança: "Ó poesia quanto te pedi!/ Terra de ninguém é onde eu vivo/ E não sei quem sou - eu que não morri/ Quando o rei foi morto e o reino dividido" (ANDRESEN, 1990, p. 223). Trata-se de uma busca que se realiza apesar da, ou por causa da, consciência do eu lírico de que o insucesso da poesia em encontrar seu objeto consiste na verdade do poema e de que, portanto, chamar uma coisa por seu nome é fazê-la aparecer em sua própria distância. Na obra, há textos que apontam exatamente nessa direção. "Poema" ( CR), em apenas três versos, evoca o silêncio como parte do poema, ao mesmo tempo em que alude aos brancos como a materialização, na página, do horizonte de invisibilidade e de indizibilidade dos objetos, a indicar que, se a referência poética não pode abolir completamente a distância que a separa das coisas, nem por isso se resigna a ela: "Poema de geometria e de silêncio/ Ângulos agudos e lisos/ Entre duas linhas vive o branco" (ANDRESEN, 1990, p.235). Desse texto a outro, intitulado "Que poema..." (CR), avança-se, pois, do branco da página - isto é o espaço das margens e aquele situado entre as linhas poéticas -, passa-se à página em branco, imaginada como possibilidade única e plena de exprimir o impronunciável, de fazer ver o invisível e coincidir com as coisas, como mostra a primeira estrofe: "Que poema, de entre todos os poemas,/ Página em branco?/ Um gesto que se afaste e se desligue tanto/ Que atinja o golpe de sol nas janelas" (ANDRESEN, 1990, p. 233).

Na poesia de Cecília Meireles, as várias aparições do mar - por vezes, identificado como reino - e a reunião do ser humano com o sagrado, bem como a ruptura dessa aliança, também são temas recorrentes. No poema "Mar absoluto" (MA), o mar, que em dado momento corre "como um touro azul por sua própria sombra", é depois "a pura sombra de si mesmo/ por si mesmo vencido". Além disso, ele é, ao mesmo tempo, "o dançarino e a sua dança", e "não precisa do destino fixo da terra", porque possui "um reino de metamorfose, para experiência" (MEIRELES, 1994, p. 266-268). Assim, por sua capacidade infinita de transformar-se em outro, esse mar figura aqui como um mar sem fundo ou sem fim, a exemplo do que se 
observou na poesia de Sophia de M. B. Andresen. Chama a atenção, ainda, a dimensão sobre-humana que, no texto de Cecília Meireles, essa paisagem adquire diante do olhar do sujeito poético. Desvela-se para ele a "face espantosa" desse mar, que se retrai tão logo é anunciada a sua dispersão no "reino de um outro mar" - o "Mar absoluto". No poema intitulado "Em voz baixa" (VM), por sua vez, o sujeito poético mostra que a sua trajetória é constituída de várias partidas em direção ao sagrado, do qual se aproxima gradativamente, até o dia em que virá a dispersar-se "no indeterminado Deus" (MEIRELES, 1994, p. 198), da mesma forma que o mar se dissipa, tal qual uma gota, no "Mar absoluto", como ocorre no texto que leva esse título. De acordo com "Velho estilo" (VM), esse dia chegará quando o corpo - "mártir" que sempre se sacrificou "para deixar passar as estrelas do espírito" - vier a tornar-se "símbolo, ideia, sonho" (MEIRELES, 1994, p.201). Antes desse momento, somente o poeta e seus semelhantes compreendem "tudo" o que o corpo já é, a transcendência que já possui "nesta marcha do infinito" e que, posteriormente, será plena. O poeta é aquele que encontra, dentro do tempo, dentro do mundo pelo qual o ser humano está de passagem, elementos que se situam em um reino fora do tempo, como se lê em "Itinerário" (VM): "Achei lugares serenos/ e aromas de fonte extinta./ Raízes fora do tempo,/ com flores vivas ainda" (MEIRELES, 1994, p. 247).

Essa experiência parece intensificar-se em "O enorme vestíbulo" (RN), poema que fala do lugar no qual o eu lírico vai-se "perdendo e libertando/ em pura matéria divina". Porém, a permanência do sujeito poético nesse local é provisória - razão pela qual pede a seu interlocutor "Deixa-me andar por muito tempo/ neste vosso enorme vestíbulo" - e seu acesso é restrito, pois chega até a entrada, mas não avança para o interior do recinto. Além disso, ao final dessa experiência e do poema, somente o eu lírico retém a lembrança, os rastros daquilo que lhe foi dado viver, como um sinal de distinção e como uma espécie de orientação para a viagem que realiza nos limites do mundo terreno, antes de alcançar, de uma vez por todas, o infinito: "Entre todos os convidados,/ eu só guardo a sombra da festa: pequena bússola em meus dedos" (MEIRELES, 1994, p. 386-388). Em "Ó luz da noite..." (SB), o sujeito poético, distinguido pela clarividência, também abre "esta porta além do mundo" e, embora não passe para o outro lado, basta-lhe "o umbral, de onde se avista o ponto certo,/ o grande vértice a que sobe o olhar do mundo" (MEIRELES, 1994 , p. 794). Em situações como essas, a relação de correspondência entre os objetos e as palavras pode ser restaurada, conforme se percebe no poema "Dois" (AN). Aí o próprio eu lírico, enquanto se manteve em contato com as nuvens, caminhando "além da terra", adquiriu outro nome, “indeclinável” (MEIRELES, p. 1994, p.464). Esse é o nome compatível com a "essência etérea e clara" que o caracteriza, a despeito do "desgosto de ser criatura" (MEIRELES, 1994, p. 133-134) que o acompanha em sua viagem terrena, como se lê em "Vinho" (VG). Essa situação ambígua do sujeito poético leva-o a falar não apenas de sua aliança com o divino, mas também de sua prisão neste mundo, durante a qual mantém "esse apego/ a um deus supremo" (MEIRELES, 1994, p. 273), como declara "Autorretrato" (MA). Na condição de exilado, ele se lamenta em alguns poemas, a exemplo do que ocorre "Valsa" (VG): "Coitado de quem pôs sua esperança/ nas praias fora do mundo..." (MEIRELES, 1994, p. 134). Na poesia de Cecília Meireles, essa divisão entre o humano e o divino provoca um efeito semelhante àquele que se observa na obra poética da autora portuguesa. Segundo os versos da escritora brasileira, quando as mãos que esperavam "o amanhecer definitivo" caem "na torrente do tempo", "o broto das palavras" é cortado "rente à boca" (MEIRELES, 1994 p. 134135), como se lê em "Grilo" (VG). Constata-se aí que a ruptura da aliança com o sagrado rouba da própria poesia o poder que detinha de dizer as coisas.

A incapacidade da poesia de atingir o próprio ser da coisa, ou de coincidir com esta, também é abordada por Cecília Meireles, tal como se vê na primeira estrofe de "Quadras" (VG), conjunto em que se evidencia o fato de que o poema fica sempre aquém daquilo que o objeto é, ou do segredo que este preserva por ser inesgotável: "Na canção que vai ficando/ já não vai ficando nada [...]" (MEIRELES, 1994, p. 156). Na poesia de Cecília Meireles, do mesmo modo que na de Sophia de M. B. Andresen, essa separação entre palavra e coisa, que resulta na decepção do poeta, afirma a irredutível alteridade dos objetos que a linguagem pretende nomear. Por isso, também para a poesia da escritora brasileira, chamar as coisas por seu nome, é tornar presente a sua ausência. Leia-se um fragmento de "Cantar" (VG): "Cantar de beira de rio:/ água que bate na pedra,/ pedra que não dá resposta.//[...]

Cantar de beira de rio:/ o mundo coube nos olhos, / todo cheio, mas vazio" ( MEIRELES, 1994, p. 154). Nesses versos, a consciência de que o referente poético não se deixa dizer ou ver completamente leva o poema a reencontrar sua origem, o silêncio. Observa-se, ainda, que a menção ao voo das palavras é, no poema 41 (MR), uma forma de evocar o silêncio como parte da poesia: "Cada palavra uma folha/ no lugar certo.// Uma flor de vez em quando/ no ramo aberto.// Um pássaro parecia/ pousado e perto.// Mas não: que ia e vinha o verso/ pelo universo" (MEIRELES, 1994, p. 777). A mesma ideia comparece em "Voo" (PM): "Alheias e nossas/ as palavras voam. [...]// E às vezes pousam" (MEIRELES, 1994, p. 1233). Essa 
alusão ao horizonte de invisibilidade e de indizibilidade dos objetos indica que, se a referência poética não pode abolir completamente a distância que a separa das coisas - uma vez que as palavras são, simultaneamente, "alheias e nossas" e que o seu pouso é raro e sempre incerto -, o poema pode incorporar o indizível, como quem guarda "a sombra da festa" avistada à distância.

Tanto na poesia de Sophia de M. B. Andresen como na de Cecília Meireles, está bem marcada a consciência de que o poema acaba reencontrando o seu horizonte último, o silêncio. E a análise feita até aqui sugere, também, que a poesia e o sagrado aproximam-se, e às vezes confundem-se, nas obras de ambas as autoras, em virtude da relação constitutiva que possuem com um horizonte de invisibilidade e de indizibilidade. Entretanto, alguns poemas das duas escritoras evidenciam esse aspecto, em vez de somente sugeri-lo, ao caracterizarem o sagrado - esteja ele aí representado por Deus, pelos deuses ou de outras formas - apontando, de modo explícito, para a experiência que supõe: a da distância entre aquilo que é dito e o indizível, entre o significado e o não significável.

Na obra de Sophia de M. B. Andresen, destaca-se a afirmação feita pelo eu lírico a seu interlocutor, no poema intitulado "Senhor" (MN): "És sempre um deus que nunca tem um rosto [...]" (ANDRESEN, 1991a, p. 47). Da mesma forma, em "Eis-me" ( LS), o sujeito poético dirige-se àquele que é "de todos os ausentes o ausente" $\mathrm{e}$ cujo rosto "está para além do tempo opaco", dizendo-lhe que a sua tentativa de reunião com ele é um "encontro" com "planícies e planícies de silêncio" (ANDRESEN, 1991a, p. 117). Se a face do sagrado é inalcançável e invisível, o acesso a ela pode ser apenas imaginado ou pressentido. De acordo com "Felicidade" (LS), trata-se, no caso do sagrado, de uma "presença incerta", "fantástica e liberta", inatingível ao olhar e reconhecida "por tudo" aquilo que "atentamente esperamos [...]" (ANDRESEN, 1991a, p. 121), constituindo-se, portanto, em um vazio que contém qualquer coisa, ou sobre o qual várias expectativas projetam-se. Presença que só se mostra escondendo-se, que jamais se cumpre, como se percebe em "Gesto" (DM) - "Eu em tudo Te vi amanhecer/ Mas nenhuma presença Te cumpriu [...]" (ANDRESEN, 1990, p.142) -, o sagrado tem como seu horizonte último o silêncio. Logo, só pode ser intuído pelo eu lírico, conforme se verifica em "Escuto" (GF): "Escuto mas não sei/ Se o que oiço é silêncio/ Ou deus// Escuto sem saber se estou ouvindo/ O ressoar das planícies do vazio/ Ou a consciência atenta/ Que nos confins do universo/ Me decifra e fita". É o mero pressentimento que determina a reação do sujeito: "Apenas sei que caminho como quem/ É olhado e conhecido/ E por isso em cada gesto ponho/ Solenidade e risco" (ANDRESEN, 1991b, p. 32).
Esse vazio que pode guardar tudo, como já foi visto, também constitui o referente poético. É por essa razão que a poesia da autora fala do sagrado e da arte do recitador - aberta sobre a abertura sem fundo do Ser - de forma semelhante. O sagrado situa-se na fronteira entre o silêncio e deus, entre o tudo e o nada, ocupando o mesmo lugar atribuído à "palavra modulada" daquele que recita em "Trípoli 76" (NC), poema do qual se transcreve a estrofe II: "O recitador entoa a palavra modulada/ Rouca de deserto e sol e imensidão/ Entoa a veemência nua da palavra/ Fronteira de puro Deus e puro nada" (ANDRESEN, 1991b, p. 231). É justamente essa ausência do referente poético e do elemento divino que mantém a busca da poetisa. A análise mostra que, nos textos da escritora portuguesa a falta ou incompletude é reconhecida como um traço que define a especificidade da experiência poética e a própria natureza do poeta. Em "Palmeiras geometria" (GF), o eu lírico alude às coisas e à paisagem; à geometria, que pode ser interpretada como a medida do canto; à aridez; ao silêncio e, por fim, à "infinita ausência": "Palmeiras geometria/ São meu alimento/ Secura silêncio/ São minha bebida/ E a infinita ausência/ É a minha vida/ A funda a secreta/ Com sabor a pedra/ E perfume de vento" (ANDRESEN, 1991b, p. 56). Com base nos poemas anteriormente examinados, talvez se possa afirmar que a vida identificada com a "infinita ausência", ao qual "Palmeiras geometria" faz menção, é a de todo poeta e, especialmente, a de Sophia de M. B. Andresen, pois sua existência é mantida pela fome e pela sede, jamais saciadas, de plenitude e de palavras. Essa falta expõe, na obra da escritora, a afinidade de estrutura existente entre o sagrado, caracterizado por sua retração, e a poesia, constituída por uma abertura que desvenda a obscuridade do Ser. Explicita-se, então, a ideia de que o poema atinge a transcendência, da qual a poetisa desfruta, ao visar a uma presença ausente, que é, simultaneamente, o sagrado e o referente poético.

Ao buscar algo que é inatingível enquanto totalidade, mas indispensável, a poetisa está sempre diante de um fundo insondável, de um "mar sem fim". Desse modo, sua existência é uma sucessão de movimentos alternados, que ora corporificam a errância, ora consubstanciam a celebração de uma unidade provisória. Essa coreografia é descrita nos poemas "Enquanto longe divagas" (NC) e em "O Minotauro" (DL). No primeiro, a errância é abordada a propósito de um "tu" a quem o sujeito se dirige. Trata-se aí de uma espécie de mergulho desse interlocutor do eu lírico em um estado de divagação que o conduz ao esquecimento da palavra e à procura de si mesmo pelos "labirintos da viagem": "Enquanto longe divagas/ $E$ através de um mar desconhecido esqueces a palavra/ - Enquanto vais à deriva das correntes/ E fugitivo perseguido por inomeadas formas/ A ti próprio te 
buscas devagar [...]". Nesse poema, percebe-se que a fuga da linguagem não é definitiva, e que a perda do poema não representa propriamente a perda da poesia. Aquele que erra pelos caminhos de um país estranho e obscuro, depois de naufragar, regressa a seu corpo na forma de "um jovem toiro espantado de se reconhecer", reinando, como o Minotauro, sobre os labirintos. Ele recupera, então, o vínculo com as coisas, que aí se confunde com o amor da palavra antes esquecida: "E devagar recuperas tua mão teu gesto / E teu amor das coisas sílaba por sílaba" (ANDRESEN, 1991b, p. 202-203). Outro aspecto a destacar em "Enquanto longe divagas" é a semelhança que se estabelece entre a experiência poética e a existência - de modo que, ao esquecimento da palavra e à sua posterior recuperação, correspondem, respectivamente, a perda de si e o "regresso" por parte do interlocutor -, constituindo-se ambas em uma totalização inacabada.

Esse inacabamento que define a experiência poética e a existência, aproximando-as, também se faz presente em "O Minotauro", quando o eu lírico descreve aquilo que denomina "a dança do ser": "O Dionysos que dança comigo na vaga não se vende em nenhum mercado negro/ Mas cresce como flor daqueles cujo ser/ Sem cessar se busca e se perde se desune e se reúne/ E esta é a dança do ser" (ANDRESEN, 1991b, p. 148). Tal como o ser "se busca e se perde se desune e se reúne", a palavra se extravia, mas pode ser reencontrada, para, então, dispersar-se de novo, e assim sucessivamente, da mesma forma que o sagrado, em suas manifestações, retrai-se e logo depois se mostra para, mais uma vez, esconderse. Conclui-se, portanto, que a "dança do ser" consiste, também, na coreografia que Sophia de M. B. Andresen executa como poetisa que é, para garantir essa condição e para tornar presente a ausência que a provoca. Mesmo em confronto com os enganos do labirinto, a poetisa mantémse fiel ao desejo ou princípio que a orienta, isto é, a busca da palavra incorruptível, como declara o eu lírico em "O Minotauro": "Porque pertenço à raça daqueles que percorrem o labirinto/ Sem jamais perderem o fio de linho da palavra" (ANDRESEN, 1991b, p. 149). E as palavras que lhe podem servir de guia nos caminhos do labirinto, conforme a autora revela no texto "Arte poética - II" (GF), não são escolhidas "esteticamente pela sua beleza", mas "pelo seu poder poético de estabelecer uma aliança" (ANDRESEN, 1991b, p.96). Essa concepção é mais um ponto de aproximação entre sagrado e poesia, elementos que, nos textos da escritora portuguesa, são inseparáveis e exibem uma afinidade quanto à sua estrutura. Além disso, salienta-se aí a ideia de que o trabalho do poeta é o de levar as palavras a se comunicarem com as coisas.

Na obra poética de Cecília Meireles, tal como se verificou na poesia de Sophia de M. B. Andresen, a presença do sagrado não pode ser confirmada pela visão.
Em "Vens sobre noites sempre..." (SB), o eu lírico chega até o umbral, mas constata que, no "mundo estranho a estas festas humanas" ao qual tem acesso parcial, há um rosto que jamais pode ser visto. Esse mundo, além de invisível, é indizível, pois não é completamente alcançável por meio da linguagem. Nele, "as palavras são conchas secas, bradando// a vida, a vida, a vida! e sendo apenas cinza", de modo que o sagrado não apenas não se dá a ver como também mergulha no silêncio, fazendo-se presente como uma ausência: "[...] Pousa// teu nome aqui, na fina pedra do silêncio,/ [...] na água que leva cada encontro para a ausência [...]" (MEIRELES, 1994, p. 787). No "Poema da fascinação" (PP), o eu lírico, ao invocar seu interlocutor, chama-o de "Eleito" e emprega o pronome oblíquo "Ti", marca da segunda pessoa do singular, grafando ambos os vocábulos com a inicial maiúscula. Nesse texto, mais uma vez, o sujeito poético procura aproximar-se do sagrado e tem como guia o olhar de um vulto, que o atrai na mesma medida em que se nega a ele, retraindo-se: "Vou a Ti,/ seguindo a luz dos teus olhos [...]/ O teu vulto,/ lá em cima,/ é um palácio branco, a atrair-me.../ Quando chegarei,/ ó Eleito,/ diante de Ti?/ Quando descerrarás/ as tuas portas [...]?” (MEIRELES, 1994, p.933).

No "Poema das bênçãos" (PP), o sujeito poético reafirma a impossibilidade de um acesso completo ao sagrado, quando declara que canta o seu "Eleito", embora tenha de viver, "[...] sempre,/ sem poder conhecê-Lo/ e sem poder encontrá-Lo..." (MEIRELES, 1994, p.947). Em "Explicação" (VM), Deus é o incognoscível que tudo conhece: "Deus não fala comigo - e eu sei que me conhece" (MEIRELES, 1994, p. 236). E em "Parusia" (PM), o eu lírico mostra que morrerá sem assistir à chegada de Cristo e que, somente no evangelho - "naquele livro dourado" -, o sagrado aparece como "Presença" plena descida do "Mistério". Nos últimos dois versos, o sujeito poético conclui "Lá eu vi a Presença, a Luz do Céu, a felicidade do mundo.// O resto aparece apenas na minha alma" (MEIRELES, 1994, p. 1233), evidenciando que a alma capta o invisível e o impronunciável, justamente porque integra à percepção que tem do sagrado o horizonte de invisibilidade e de indizibilidade que lhe é inerente. "Velho estilo" (VM), poema já comentado, reitera essa noção. Aí o eu lírico dirige-se a seu interlocutor, que é inatingível, utilizando a expressão "Coisa que passas" e perguntando-lhe qual é o seu nome, ao mesmo tempo em que afirma: "Tua presença nalguma parte/ é já sinal da tua partida". O único vestígio ou rastro desse ser que permanece depois que "tudo se apaga" é a expectativa ou o desejo de ter ao alcance das mãos aquele que se ausenta: "No ardente nível desta experiência,/ [...] tudo se apaga, preso em sigilos:/ mas no desenho do último gesto,// há mãos de amor para a tua ausência" (MEIRELES, 1994, p.202). Assim, o sagrado, tal como o referente poético, 
é um vazio que pode guardar tudo, conforme se verifica pela pergunta que o eu lírico faz a seu interlocutor em "Rimance" (VM): "Por que me destes um corpo,/ se estava tão descansada,/ nisso que é talvez o Todo,/ mas parece tanto o Nada?" (MEIRELES, 1994, p. 250-251).

Esse encontro entre as experiências poética e mística é abordado em inúmeras ocasiões na poesia de Cecília Meireles. Se, em um poema antes examinado, a poetisa é a "pastora de nuvens" que tenta reunir um gado sempre ameaçado de extravio, no texto intitulado "Meu pasto é depois do dia, dos horizontes" (PM), ela assume a condição de rebanho que pasta em uma "grande mão invisível" e "eterna" (MEIRELES, 1994, p. 1208-1209). Por sua vez, no poema 14 (MR), a proximidade entre essas duas experiências é tal que a ligação entre a alma e o universo, já desfeita, é definida como "um poema" que "parecia perfeito: "Houve um poema,/ entre a alma e o universo./ Não há mais./ [...]// Houve um poema:/ parecia perfeito./ Cada palavra em seu lugar,/ como as pétalas nas flores [...]" (MEIRELES, 1994, p. 778-779). Esse poema, que tem como "um rastro de sua cor" o "coral do horizonte", e do qual o eu lírico "já" não se lembra e "ainda" se lembra, parece fazer eco à cantiga que o sujeito poético deseja cantar, mas não consegue (MEIRELES, 1994, p.313-314), em "Inibição" (MA), o que talvez se possa interpretar como uma falha da poesia em seu intento de reunir o mundo humano ao sagrado. Se essa cantiga não se concretiza, de acordo com as hipóteses do eu lírico, por ser tardia ou precoce, é sinal de que ela fala - por meio de uma voz que não soa - da aliança quebrada e ainda não restaurada, ou só provisoriamente restabelecida. Talvez por essa mesma razão, em "Diálogo" (VG), o eu lírico defina suas palavras como "[...] a metade de um diálogo obscuro/ continuando através de séculos impossíveis" (MEIRELES, 1994, p. 138). Assim, no momento presente, o sujeito poético não poderia ser feliz nem mesmo com a "glória", que tornaria grande parte dos seres humanos satisfeitos. Essa impossibilidade deve-se ao fato de que ele, como demonstra "Transeunte" (VG), está voltado para o passado e, simultaneamente, para o futuro, ou seja para o período em que a sua unidade com o divino ainda não havia sido destruída e para o instante em que essa mesma unidade voltará a existir. Desse modo, o sujeito poético é aquele que, tendo "intuições" e "memória”, vive "construindo apenas Deus..." (MEIRELES, 1994, p. 329).

Se o poema que ligava a alma ao universo esvaiu-se, o que está "brotando pela noite lisa", como se afirma em "Embalo" (VM), são "[...] as lágrimas de uma canção/ pelo que não se realiza...”, (MEIRELES, 1994, p. 204), restando ao poeta dizer a saudade daquilo que foi e a espera pelo que virá. Como se verifica em "Canção quase inquieta" (VM), todo ser humano, possuindo uma alma que é divina e um corpo que a mantém durante sua passagem pelo mundo terreno, permanece, no decorrer dessa viagem, entre "estandartes do vento" e "sepulcros fechados". Todavia, é o poeta que experimenta com mais intensidade essa condição ambígua - "E eu me partindo, dentro de mim" -, ao esforçar-se "[...] para estar no mesmo momento/ de ambos os lados" (MEIRELES, 1994, p. 187). Portanto, esse lugar intermediário é a marca que define todo poeta e, acima de tudo, o traço que distingue, especificamente, uma poetisa: Cecília Meireles. Leia-se a última estrofe de "Noite" (MA), poema antes comentado, no qual o eu lírico feminino indaga a Deus sobre o seu estado: "Pergunto a Deus se estou viva,/ se estou sonhando ou acordada./ Lábio de Deus! - Sensitiva/ tocada" (MEIRELES, 1994, p. 336). Dessa forma, em "Interpretação" (MA), pode-se ver o ato de interpretar como uma menção à condição do poeta, que, embora vivendo entre os demais seres humanos, desempenha outro papel ou, desde já, tem acesso parcial a outra existência: "[...] meu mundo é feito de outra vida/ Talvez nós não sejamos nós”. Entretanto, também parece surgir daí outro significado, pois interpretar é um ato que se deseja ver realizado pelas palavras, anseio que pode conduzir à frustração, uma vez que a capacidade que a linguagem tem de dizer fica aquém do conhecimento que a alma do poeta detém: "As palavras aí estão, uma por uma:/ porém minha alma sabe mais" (MEIRELES, 1994, p. 307). Assim, o poema é um convite feito aos lábios para que eles verbalizem a incapacidade e, ao mesmo tempo, o desejo da poesia de falar daquilo que, mesmo lembrado ou intuído, nunca é inteiramente atingido: o ser das coisas e o sagrado. O verbo "falar" - "falai" - no imperativo, acompanhado do ponto de exclamação nos dois versos em que se faz presente, figura, então, como uma interpelação da poetisa ao "lábio fatigado de ais", logo a si mesma, para que interprete o horizonte de indizibilidade que cerca tanto o seu rebanho, a matéria poética, como o seu pasto, isto é, os rastros do sagrado que a alimentam e que, simultaneamente, provocam nela uma fome impossível de ser saciada.

Em "Personagem" (VG), afirma-se que a "arte de amar é exatamente/ a de ser poeta". Pode-se pensar, com base nessa frase e nos demais textos comentados, que o poeta, ao lidar com um referente sempre cercado pelo silêncio e pela invisibilidade, domina uma arte que coincide, em sua natureza, com a arte de interpretar o sagrado. Quando declara seu amor por um interlocutor "sem forma e sem nome", que existe "silencioso, obscuro e disperso", o eu lírico explica que, para pensar nesse ser não nomeado, basta-lhe "o próprio amor" que sente por ele. É justamente essa falta, essa ausência do referente poético e do elemento divino que mantém a busca da poetisa: "[...] eu procuro o que não se avista". Assim, ao 
visar à transcendência, isto é, ao procurar por algo que é inacessível enquanto totalidade, mas imprescindível, a poetisa vê-se sempre diante de um abismo: "E, nesse abismo do meu sonho,/ alheia a todo outro desejo,/ me decomponho e recomponho..." (MEIRELES, 1994, p. 164-165). A decomposição que experimenta advém de sua dupla condição, do fato de estabelecer vínculos com o divino, mesmo sendo criatura humana, mas também deriva da estrutura da poesia e do sagrado, uma vez que, por meio de ambos, a poetisa reconquista sua unidade ao mesmo tempo em que se perde e se dissipa no todo. Muitos desses aspectos são explicitados e/ou desenvolvidos em "Recitativo próximo a um poeta morto" (PM), escrito por ocasião da morte de Jorge de Lima, no qual o eu lírico afirma: "Que é o poeta/ senão o burlador das fronteiras da vida [...]?". O poeta é capaz de burlar essas fronteiras, "porque já não é humano, e ainda é humano"; porque vê e ouve mais do que todos os outros seres humanos, mas não pode ver e ouvir tudo, pois tem acesso limitado ao ser das coisas e ao sagrado; porque não é "“...] Deus, nem profeta, nem sábio/ mas tudo isso, imperfeitamente e amargamente [...]" (MEIRELES, 1994, p. 1065-1067).

Esse ser "múltiplo, complexo,/ contraditório,/ solitário e plural", esse "aprendiz de Criador", "demiurgo" a balançar-se "em aéreos fios de Efêmero e Eterno", possui uma voz, que é e não é sua, em que se reconhecem os mesmos atributos que o distinguem e que, sendo fragmento de uma totalidade, é reverberação da "voz única" e una de que faz parte -, "Correspondência de mil vozes,/ trecho de uma voz única,/ uma só linguagem,/ traduzida em mil idiomas, em mil imagens" -, de modo que também aponta para a reunião entre poesia e sagrado: "toda fragmentada, nessa queda violenta do mistério,/ e, no entanto, dúctil,/ com uma unidade antiga e mágica,/ acima, além de seu poder e conhecimento". A voz do poeta, sua e alheia, é "esforçado eco" (MEIRELES, 1994, p. 1067-1068). Trata-se, como na poesia da escritora portuguesa, de buscar uma comunicação com as coisas por meio das palavras.

\section{Considerações finais}

A análise comparativa das obras de Sophia de M. B. Andresen e de Cecília Meireles demonstra que essas autoras se aproximam na forma de abordar a afinidade de estrutura entre poesia e sagrado e, também, na atenção que dedicam a tal temática em seus textos. Entretanto, a sintonia entre as duas poetisas vai além desse aspecto, inscrevendo-se, inclusive, no modo como o eu lírico posiciona-se e constitui-se em relação às diversas aparições desses elementos. Diante de uma ausência que se faz presente, que se promete nas imagens, porém nunca se dá a ver inteiramente, que pede para ser dita, embora seja indizível, o sujeito poético empenha-se, nos versos de ambas as escritoras, em ver "como quem vê outra coisa", em dizer o silêncio. Assim, ele assume a dupla condição dos seres que, em alguns instantes, acercam-se da transcendência, mas logo a perdem de vista e precisam prosseguir na sua busca. Essa situação ambígua define a coreografia executada pelo eu lírico - a "dança do ser", no caso de Sophia de M. B. Andresen e o "embalo", no caso de Cecília Meireles -, que "sem cessar se busca e se perde se desune e se reúne". Ao situarem sua poesia nessa "fronteira de puro Deus e puro nada", as duas autoras convertem-se em "pastoras de nuvens", exibindo uma distinção que implica o acesso a um reino "fora do tempo" e, simultaneamente, a consciência de uma permanente instabilidade e a convivência com a perda e a precariedade que caracterizam a existência humana.

\section{Referências}

ANDRESEN, Sophia de Mello Breyner. Obra poética I. Lisboa: Caminho, 1990.

ANDRESEN, Sophia de Mello Breyner. Obra poética II. Lisboa: Caminho, 1991a.

ANDRESEN, Sophia de Mello Breyner. Obra poética III. Lisboa: Caminho, 1991b.

ANDRESEN, Sophia de Mello Breyner. A poesia de Cecília Meireles. Metamorfoses, [S.l.], v. 1, n. 1, p. 61-71, 2000.

COLLOT, Michel. La poésie moderne et la structure d'horizon. Paris: PUF, 1989. https://doi.org/10.3917/puf. collo.2005.01

COLLOT, Michel. La matière-émotion. Paris: PUF, 1997.

COLLOT, Michel. Le corps cosmos. Bruxelles: La Lettre Vollée, 2008

COLLOT, Michel. Poética e filosofia da paisagem. Tradução de Ida Alves et al. Rio de Janeiro: Oficina Raquel, 2013.

MEIRELES, Cecília. Poesia completa. Rio de Janeiro: Nova Aguilar, 1994

Recebido em: 02/04/2019.

Aprovado em: 02/04/2019.

Publicado em: 21/06/2019.

Autora:

Márcia Helena S. Barbosa

Doutora em Teoria da Literatura, professora do PPGL-UPF e membro do Grupo de Pesquisa Estudos de Paisagem nas Literaturas de Língua Portuguesa (UFF).

Orcid: http://orcid.org/0000-0002-0157-8045

E-mail:mhsbarbosa@gmail.com

Endereço: Universidade de Passo Fundo

Instituto de Filosofia e Ciências Humanas - Curso de Letras

Campus 1, Prédio B4 - São José

Caixa-postal 611

99001970, Passo Fundo, RS, Brasil 